ANDRZEJ NOWAK

Instytut Historii PAN, Warszawa

\title{
IZOLACJONIZM I APPEASEMENT: WASZYNGTON I LONDYN WOBEC IMPERIUM SOWIECKIEGO ORAZ POLSKIEGO KRYZYSU LATEM 1920 R.*
}

W ostatnim dniu 1919 r. Samuel Breckenridge Long (1881-1958), trzeci wówczas asystent sekretarza stanu USA i najinteligentniejszy bodaj uczestnik amerykańskiej delegacji na paryską konferencję pokojową, zapisał w swoim prywatnym dzienniku taką oto prognozę:

możliwości przyszłych problemów grożą tak na wschodzie jak i na zachodzie. Działania Japonii i poszerzanie jej dominium wywołują niepokój jako czynnik generujący problemy, gdyż prędzej czy później znajdzie się ona w konflikcie z naszymi interesami. Na drugiej półkuli bolszewizm może stać się tak silny, że dokona najazdu na Polskę, Czechosłowację i Węgry. Jeśli tak zrobi, wówczas Włochy z pewnością dołączą [do tej listy], Niemcy zaś może staną po stronie Rosji, żeby uniknąć straszliwych kar nałożonych przez aliantów w traktacie [wersalskim]. [--] Jeśli,jak się spodziewam, bolszewicy dokonają militarnego uderzenia na Polskę, osiągną sukces i będą kontynuowali marsz na zachód, nic nie zatrzyma ich na wschód od Renu i Francja może upaść. Ale to już w przyszłym roku - albo później. Finis $1919^{1}$.

* Tekst przygotowany w ramach Programu Mistrz Fundacji na rzecz Nauki Polskiej „Historie i pamięci imperiów Europy Wschodniej: studia porównawcze / Histories and Memories of Empires in Eastern Europe: Interactive Studies".

1 ,the possibilities of future troubles looms over the horizon from east and from west. Japan's activities and her extension of dominion loom large as factors of trouble for sooner or later she will be in conflict with our affairs. In other hemisphere Bolshevism may become so strong it will over-run Poland, Czecho-Slovakia and Hungary. If it does - Italy is sure to join and Germany may side with Russia to escape the terrible penalties imposed by the Allies in the treaty. [--] If, as I expect, the Bolshevics make a military drive against Poland, are successful and continue their westward march 
Wrażenie największe słowa te wywołują nie tylko przez ich swoiście proroczy sens, ale także poprzez ujawnione w nich poczucie bezsilności - bezsilności tych, którzy wygrali właśnie wielką światową wojnę i mieli urządzać nowy porządek dla wszystkich narodów. Kiedy w styczniu 1919 r. zbierała się Konferencja Pokojowa w Paryżu, jej podstawowe zadanie zostało dobitnie określone przez jednego z członków amerykańskiej delegacji: „wprowadzić porządek na miejsce chaosu w praktycznie całej Europie na wschód od Renu"2. Takie w każdym razie było przekonanie przywódców zwycięskich w Wielkiej Wojnie mocarstw - że powinni i że są w stanie zbudować nowy porządek. Rozumieli go w sposób różny, spierali się o jego sens i kształt, a spory te mają do dziś ogromną już literaturę przedmiotu. Zgadzali się jednak pod tym względem, że mają prawo, a nawet obowiązek moralny wynegocjowany między sobą porządek wprowadzić na całym obszarze, który ogarnęła Wielka Wojna.

Utrzymanie tego ładu, jaki chciały wprowadzić mocarstwa Ententy, wymagało użycia siły: militarnego i/lub finansowego nacisku. Jak to ujęła wybitna badaczka systemu wersalskiego, Margaret Macmillan (prawnuczka premiera Davida Lloyda George’a) — „Mocarstwowość wiąże się z wolą [- ]: wolą czy to wydawania pieniędzy, czy to narażania życia [swoich obywateli]. W 1919 r. ta wola została wśród Europejczyków złamana; Wielka Wojna oznaczała, że przywódcy Francji, czy Brytanii, czy Włoch nie mieli już zdolności do nakazywania obywatelom swoich krajów, by płacili wyższą jeszcze cenę za status mocarstwa"3.

Tej woli zabrakło jednak nie tylko w wyczerpanym całkowicie wojną Paryżu, zadłużonym Londynie, ale także w Waszyngtonie. Zwłaszcza w sprawie Rosji, w sprawie europejskiego wschodu. A od rozstrzygnięcia problemu rosyjskiego właśnie zależało ostateczne utrwalenie lub zdestabilizowanie całego systemu wersalskiego. Do wiosny 1920 r. mocarstwa Ententy wraz ze Stanami Zjednoczonymi nie potrafiły tej kwestii rozwiązać ani też nie doczekały się jej satysfakcjonującego (dla nich)

nothing will stop them east of the Rhine and France may succumb. But that is in next year, - or after. Finis 1919", Library of Congress, Manuscript Division, Washington, D.C. (dalej: LC), Breckenridge Long, ,Diary”, 1919, Breckenridge Long Papers, Container 2.

${ }^{2}$ Tymi słowami (,to bring about order out of chaos in practically all of Europe east of the Rhine") - zadanie Konferencji streścił prawny doradca delegacji amerykańskiej, David Hunter Miller. Cyt. za: A. J. Mayer, Politics and Diplomacy of Peacemaking. Containment and Counterrevolution at Versailles, 1918-1919, New York 1967, s. 8.

3 „Power involves will [--]: the will to spend, whether it be money or lives. In 1919 the will had been crippled among the Europeans; the Great War meant that the leaders of France or Britain or Italy no longer had the capacity to order their peoples to pay a high price for power", M. Macmillan, Peacemakers. Six Months that Changed the World, London 2001, s. 7. 
rozwiązania. Brakowało im do tego sił, a raczej, na pewno, woli ich użycia - przez zmęczone Wielką Wojną społeczeństwa - w tej skali, jakiej wymagałaby próba narzucenia Rosji, największemu terytorialnie (po brytyjskim) imperium świata, rozwiązań, jakie „pasowałyby” do wymarzonego przez zwycięskie mocarstwa nowego, powojennego porządku.

Prezydent USA Thomas Woodrow Wilson pamiętany jest powszechnie jako propagator hasła prawa narodów do samookreślenia, rzuconego ostatecznie na stół obrad paryskiej konferencji pokojowej. W Polsce - dodatkowo - utrwalił się w historycznej pamięci obraz amerykańskiego prezydenta jako głównego championa sprawy polskiej niepodległości w $1918 \mathrm{r}$. W istocie rzeczy wielki projekt Wilsona zakładał przekreślenie polityki zagranicznej poszczególnych państw.Faktycznie jednak pierwsze miały z niej zrezygnować państwa mniejsze. Główne mocarstwa, spełniające nadzieje amerykańskiego prezydenta na przyjęcie liberalnego modelu politycznego, miały pozostać na straży nowego porządku. Naturalnym dopełnieniem wizji Wilsona była sformułowana dopiero po latach przez Franklina Delano Roosevelta koncepcja „czterech policjantów” - wielkich mocarstw, jedynie uprawnionych do posiadania armii i polityki zagranicznej „kontrolerów" międzynarodowego ładu. Faktycznie jednak owo dopełnienie było już wpisane w program samego Wilsona. W owym połączeniu liberalnego idealizmu z geopolitycznym tradycjonalizmem było miejsce tylko dla Polski „małej”, zorganizowanej w taki sposób, by harmonizowała z projektem odrodzonej, demokratycznej Rosji. W tej części świata bowiem to Rosja była „naturalnie” predestynowana do roli dobrego stróża międzynarodowego porządku. „Naturalność”, z jaką polityka Wilsonowska przyjmowała taką właśnie ocenę Rosji, wiązała się z jednej strony ze swego rodzaju przyzwyczajeniem większości (także amerykańskich) kręgów dyplomatycznych do dominującej roli rosyjskiego imperium w Europie Wschodniej, z drugiej ze specyficzną wiarą prezydenta (podzielaną przez wielu jego współpracowników z Partii Demokratycznej), że Rosja jest najlepszym partnerem dla Stanów Zjednoczonych: choć zmuszona znosić w swej historii ucisk tyranów, pozostaje zawsze „demokratyczna w głębi serca”4.

Nad tą sympatią do Rosji i wrażliwością na jej integralność terytorialną (w granicach z 1914 r., z ewentualnym wyłączeniem polskiej „Kongresówki" oraz Finlandii) bardzo efektywnie pracował w kręgu Departamentu Stanu oraz wpływowych kół prasy amerykańskiej Boris Bachmietiew (Boris Aleksandrovič Bahmet'ev). Ostatni poseł republikańskiej Rosji z 1917 r.

${ }^{4}$ Dobrą syntezę założeń Wilsonowskiego programu dla powojennego świata i miejsca Polski w owym programie przedstawił Mieczysław Biskupski, The Wilsonian View of Poland: Idealism and Geopolitical Traditionalism, w: Wilsonian East Central Europe. Current Perspectives, red. J. S. Micgiel, New York 1995, s. 123-145. 
dysponował w swych zabiegach na rzecz obrony interesów Rosji ogromną sumą ponad $50 \mathrm{mln}$ dolarów, jakie Rząd Tymczasowy otrzymał w formie pożyczek na zakupy sprzętu wojskowego w Stanach Zjednoczonych ${ }^{5}$. Główną tezą, z jaką udawało się Bachmietiewowi docierać osobiście do prezydenta Wilsona, sekretarza stanu - Roberta Lansinga (i jego zastępców, Franka Polka i Normana Hesekiah Davisa), do Herberta Hoovera i wielu innych najbardziej wpływowych osobistości nad Potomakiem, była prosta: Rosja demokratyczna odrodzi się niezawodnie, a główną przeszkodą dla jej odbudowy może być tylko pochopna zgoda mocarstw zachodnich na "rozbiór Rosji”, czyli usankcjonowanie niepodległości nowych państw na terytorium wykrojonym z niedawnego imperium Romanowów. Takie handlowanie rosyjską własnością przez Zachód, argumentował Bachmietiew, może najbardziej przyczynić się do wzmocnienia pozycji bolszewików w samej Rosji - traktowanych wówczas jako obrońcy jej integralności, jej wielkości przed „imperializmami” rozmaitych krajów, takich jak Polska, Gruzja, Łotwa, Estonia, czy Ukraina ${ }^{6}$.

Podobną nieco do Bachmietiewa rolę odgrywał w Waszyngtonie John Spargo, entuzjasta rosyjskiej rewolucji lutowej, do 1915 r. członek partii socjalistycznej w USA, autor pierwszej napisanej za oceanem biografii Karola Marksa, zaangażowany przez prezydenta Wilsona do pracy propagandowej na rzecz przełamywania niechęci amerykańskiego społeczeństwa do udziału w wojnie światowej. Podobnie jak Bachmietiew, Spargo dysponował bezpośrednim dostępem do ucha prezydenta. Jego znaczenie jeszcze wzrosło, kiedy w lutym 1920 r. z funkcji sekretarza stanu zrezygnował skłócony z Wilsonem Lansing, a od marca zastąpił go pozbawiony większego doświadczenia w sprawach międzynarodowych Bainbridge Colby. Traktował on Spargo jako najbardziej zaufanego doradcę w sprawach Rosji i Europy Wschodniej. Spargo i Bachmietiew zachowają zgodny wpływ na formułowanie podstawowych dokumentów amerykańskiej polityki za-

${ }^{5}$ Zob. O.V. Budnickij, Posly nesuŝestvuû̂sej strany, w: „Soveršenno lično i doveritelno!”. B. A. Bahmetev - V.A. Maklakov. Perepiska.1919-1951, t. 1: (avgust 1919 - sentâbr' 1921), red. O.V. Budnickij, Moskva-Stanford 2001, s. 51-79; L. Killen, The Search for a Democratic Russia: Bakhmetev and the United States, "Diplomatic History”, vol. 2, 1978, nr 3, s. 237-256; M. Mazurek, Great Britain, The United States and the Polish-Soviet Peace Treaty of Riga, 1920-1921, „Niepodległość”, t. 21 (po wznowieniu), 1988, s. 59-63; G. Kennan, Soviet-American Relations, t. 2: The Decision to Intervene, Princeton, N. J. 1958, s. 322-323; B. Winid, W cieniu Kapitolu. Dyplomacja polska wobec Stanów Zjednoczonych Ameryki 19191939, Warszawa 1991, s. 63-67.

${ }^{6}$ Zob. LC, Bainbridge Colby Papers, Correspondence, 3 A, May-August 1920, listy B. Colby'ego do B. Bakhmeteva z 13 VI 1920 z podziękowaniem za jego memoriały z 28 V i 7 VI 1920 „regarding the latest Polish advances”. 
granicznej wobec tego obszaru w ciągu 1920 r. ${ }^{7}$ Tylko półżartem można dodać, że na sympatię administracji prezydenta Wilsona, a przede wszystkim samego jej zwierzchnika, dla zasady zachowania całości terytorialnej imperialnej Rosji mógł wpłynąć także fakt, że jednym z nielicznych polityków amerykańskich (czy szerzej - anglosaskich) wypowiadających się życzliwie o Ukrainie i możliwości jej oderwania od Rosji był Henry Cabot Lodge: republikański arcywróg prezydenta ${ }^{8}$.

Wydaje się jednak, że to nie zakulisowe zabiegi czy wpływy pojedynczych agentów interesu Rosji (republikańskiej) i nie indywidualne tylko sympatie czy antypatie prezydenta, ale przede wszystkim generalna wizja nowego porządku światowego, jaką demokratyczna administracja Wilsona konsekwentnie ujawniała i próbowała wcielać w życie w latach 1918-1920, decydowała o stosunku Waszyngtonu do Rosji, do bolszewizmu i rozpatrywanej w kontekście tych wyzwań Polski. Rosja była traktowana jako wielki sojusznik w Wielkiej Wojnie - już z tego powodu trzeba było jej pomóc. Po drugie, w Waszyngtonie uznawano kluczową rolę Rosji dla gospodarki światowej - w szczególności dla odzyskania równowagi na rynku żywności, której przedwojenna Rosja była istotnym eksporterem, a także dla samej gospodarki amerykańskiej - producenta towarów na tak chłonny do 1914 r., dynamiczny rosyjski rynek zbytu. Po trzecie wreszcie - Rosja stała się terenem wielkiego eksperymentu ideologicznego: bolszewizmu. Był on oceniany jako zło i niebezpieczeństwo i przez Wilsona, i przez obu jego w tym czasie sekretarzy stanu - Lansinga i Colby'ego.

Jak znaczna część opinii liberalnej tego czasu, zwłaszcza w krajach anglosaskich, Wilson był jednak skłonny traktować powrót do systemu carskiego jako większe zło od bolszewizmu. „Zachodni liberałowie byli

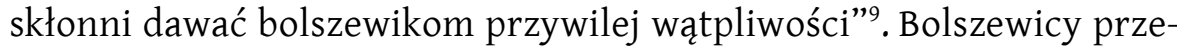
prowadzają eksperyment, okrutny, dziki, ale odpowiadający na realne bolączki i krzywdy, które zrodził „stary” system. Bolszewizmu nie pokona się siłą militarną, ale odbudową ekonomiczną i moralną, której beneficjentem powinien być przede wszystkim „lud rosyjski” - jedyny uprawniony gospodarz (wielkiej) Rosji, zatem trzeba uznać z góry fiasko

${ }^{7}$ Zob.np. LC, Bainbridge Colby Papers, Correspondence, 3 A, May-August 1920, listy J. Spargo do B. Colby'ego z 31 VII 1920; z 14 VIII tr. - podziękowanie za notę w sprawie Rosji i Polski; z 27 VIII - „Secretery Colby's Advice to Poland”; por. R. Radosh, John Spargo and Wilson's Russian Policy, 1920, „Journal of American History” 1965, vol. 52, nr 3, s. 548-565; M. Mazurek, op. cit., s. 55-63, 98-99.

${ }^{8}$ Zob. M. Macmillan, op. cit., s. 79.

9 "Western liberals were inclined to give the bolsheviks the benefit of the doubt". M. Macmillan, op. cit., s. 75; por. A.J. Mayer, op. cit., s. 328-329. 
wszelkiej zewnętrznej interwencji. Tylko sami Rosjanie mogą odrzucić bolszewizm. Należy dać szansę Rosjanom na uspokojenie, na odnowę gospodarczą, wymianę - a nie walkę - ze światem zewnętrznym. Wtedy bolszewicy stracą poparcie. To poparcie urośnie natomiast, kiedy będą mogli występować jako obrońcy całości terytorium dawnego imperium przed uroszczeniami „małych nacjonalizmów”: tu linia rozumowania Departamentu Stanu, ale także samego Wilsona, spotykała się doskonale $\mathrm{z}$ argumentami, jakimi wzmacniali ją Bachmietiew czy Spargo. Nieinterwencja i nieuznawanie zmian terytorialnych, które uszczupliłyby terytorium państwowe Rosji (poza obszarem „etnograficznej” Polski oraz Finlandii) - to były jedyne zasady polityczne, jakie mogły z takiej oceny sytuacji wynikać. I w praktyce amerykańskiej polityki wobec Rosji i Europy Wschodniej w 1920 r. wynikały.

Dla Polski, bezpośrednio sąsiadującej z tak traktowaną bolszewicką Rosją,jednoznaczne sugestie wynikające $\mathrm{z}$ takiej polityki były następujące: nie przekraczać na wschodzie linii Bugu i czekać, aż Rosja przezwycięży w sobie komunistyczną chorobę, a następnie dołączy znów - po demokratycznym odrodzeniu - do wąskiego grona współtwórców światowego ładu. Otwarte jednak pozostawało pytanie o realizm takiej oceny bolszewizmu: czy rzeczywiście wytraci on swoją zdolność do ekspansji i swoją popularność w samej Rosji zanim spróbuje rozszerzyć się - zgodnie przecież ze swymi założeniami ideologicznymi - przede wszystkim do Europy, przez Polskę? Na to pytanie można było odpowiedzieć tylko eksperymentalnie: cofnąć się na linię Bugu, która jako granica polskich aspiracji niepodległościowych na wschodzie może nie będzie drażniła rosyjskiego „ludu”, nie uznawać stojących za Bugiem bolszewików i... czekać na ekonomiczną i moralną odmianę w samej Rosji. W żadnym zaś wypadku nie przeszkadzać takiej odmianie jakimkolwiek gwałtownym ruchem, naciskiem militarnym, zabezpieczającym od wschodu polską niepodległość.

Istotnym ograniczeniem refleksji polityków mocarstw zachodnich nad konfliktem wschodnioeuropejskim w 1920 r. (i w następnych dziesięcioleciach niejednego z historyków ich działań) była dysproporcja poznawcza czy konceptualna w ich spojrzeniu na postępowanie Warszawy z jednej strony i Moskwy z drugiej. Mogli oni dysponować stosunkowo dużą wiedzą na temat celów polityki polskiej: działały wszak ich poselstwa w Warszawie, przedstawiciele dyplomacji oraz prasy angielskiej, francuskiej, amerykańskiej czy włoskiej mieli stały, łatwy dostęp do polskich ministrów, wyższych urzędników czy do samego Naczelnika Państwa. Interpretowali uzyskiwane od nich informacje o polskich dążeniach w zrozumiałych dla siebie, choć niekoniecznie i nieczęsto w odniesieniu do Warszawy akceptowanych, kategoriach aspiracji polityki narodowej. Dostępna w gabinetach Londynu 
czy Paryża wiedza o dążeniach, możliwościach i ograniczeniach polityki sowieckiej była natomiast nieporównanie mniejsza. Włodzimierz Lenin (Vladimir Il'ič Lenin), Lew Trocki (Lev Davidovič Trockij), nie mówiąc już o Józefie Stalinie (Iosif Vissarionovič Stalin) i Lwie Kamieniewie (Lev Borisovič Kamenev) (pozostałych dwóch gerentach polityki sowieckiej w 1920 r.), byli praktycznie poza zasięgiem wiarygodnych, stałych źródeł informacji opinii publicznej mocarstw zachodnich. Co jeszcze ważniejsze, te informacje na temat sowieckiej strategii i polityki, które docierały do zachodnich stolic, interpretowane w nich były często w sposób wypaczający ich sens. Były one bowiem dostosowywane do kategorii, jakimi rozumowali sami przywódcy zwycięskich mocarstw: interesu narodowego czy imperialnego. Mało, czasem w ogóle nie zostawało w owych interpretacjach miejsca na znaczenie ideologii komunistycznej, na wynikające z niej specyficzne cele i dążenia.

Ze spojrzenia, jakie rzucała amerykańska administracja na Europę Wschodnią na progu 1920 r., wynikało jednoznacznie, że jakakolwiek samodzielna akcja Polski może być tylko szkodliwa. Kiedy Polska na taką akcję, wobec bierności mocarstw zachodnich, zdecydowała się w kwietniu 1920 r., Stany Zjednoczone znajdowały się już na marginesie europejskiej polityki. Prezydent Wilson wciąż nie mógł dojść do pełni sił po swym wylewie sprzed ponad pół roku. Przede wszystkim jednak 19 marca Senat USA odrzucił traktat wersalski: do wymaganej dla zaakceptowania tej umowy międzynarodowej większości $2 / 3$ zabrakło siedmiu głosów. Triumfowała republikańska opozycja, odwołująca się do kwestii zagrożenia suwerenności działania Stanów Zjednoczonych przez możliwe skutki przyjęcia Statutu Ligi Narodów, wpisanego do traktatu. Prezydent Wilson musiał odczuwać gorycz twórcy, którego wymarzone dzieło - w tym przypadku nader ambitne: nadzorowany przez Stany Zjednoczone nowy porządek światowy wymyka mu się z rąk. Oczywiście Ameryka nie mogła wycofać się zupełnie z polityki światowej (i nie takie były przecież intencje republikańskiej opozycji). Do Waszyngtonu będą nadal płynęły apele o wsparcie - gospodarcze, dyplomatyczne, propagandowe - rozmaitych koncepcji urządzenia powojennej Europy i zmian w owym urządzeniu, USA zaś utrzymają możliwości wpływania na losy tych koncepcji. Ameryka oddaliła się jednak po decyzji Senatu od Europy.

To była sytuacja i perspektywa, w jakiej formowało się stanowisko Waszyngtonu wobec pierwszej wielkiej próby sowieckiej ekspansji do Europy, latem 1920 r., kiedy Armia Czerwona zbliżała się do Warszawy, tak jak przewidział to siedem miesięcy wcześniej Breckenridge Long (od czerwca 1920 r. zrezygnował z pracy w Departamencie Stanu, by powrócić do niej we wrześniu roku 1939...). Co robić? Czy coś robić w ogóle w tej sytuacji? 
Pytanie to wróciło w dramatycznej formie apelu, jaki przedstawił w swoim memoriale poseł amerykański w Warszawie, Hugh Gibson ${ }^{10}$. Wskazując na bezpośrednie zagrożenie niepodległości Polski przez atakującą stolicę Armię Czerwoną, Gibson prosił, by prezydent Wilson zechciał zmobilizować swoim osobistym wystąpieniem zachodnich aliantów (zwłaszcza Wielką Brytanię) do adekwatnej reakcji na to zagrożenie nie Polski tylko, ale całego porządku europejskiego. Odpowiedź prezydenta skierowana do Colby'ego nie pozostawiała złudzeń: „Drogi Panie Sekretarzu: Raczej nie mogę się zgodzić z sugestią pana Hugh Gibsona, ponieważ uważam, że minął już czas, kiedy moja osobista interwencja czy sugestia w dziedzinie polityki zagranicznej byłaby skuteczna, choć jestem głęboko zainteresowany wszystkim, co dotyczy Polski i chętnie zrobiłbym wszystko, co uważałbym za pomocne dla niej"11. Ta deklaracja bezradności prezydenta największego już wtedy mocarstwa świata występuje w jeszcze mocniejszych barwach, kiedy zestawimy ją z deklaracją jeszcze większej bezradności ze strony Departamentu Stanu wobec sytuacji, jaką stworzyła sowiecka inwazja na Polskę. Kiedy poseł amerykański z Warszawy przekazywał gorący apel o pomoc dla Polaków, jego kolega z Londynu słał z kolei prośbę (zgodnie z nastawieniem miejscowego, czyli brytyjskiego rządu) o przekonanie prezydenta do zgody na negocjacje $z$ bolszewikami w Londynie. Sekretarz stanu odpowiadał na ten list z dosłownie rozbrajającą szczerością: „Proszę wziąć pod uwagę, że informacje [jakie docierają do] Departamentu [Stanu] na temat wielu istotnych faz sytuacji [w wojnie sowiecko-polskiej] są fragmentaryczne i wzajemnie sprzecznie"12.

Od początku 1920 r. brytyjski premier konsekwentnie zabiegał o zgodę $\mathrm{z}$ aktualnymi gospodarzami Kremla. Zdołał, mimo biernego oporu Francji, zainicjować rozmowy handlowe z przedstawicielami Moskwy Lenina, ma-

${ }^{10}$ LC, Bainbridge Colby Papers, Correspondence, 3 A, May-August 1920, list B. Colby’ego do prezydenta W. Wilsona z 18 VII 1920, przekazujący dzień wcześniejszy apel posła H. Gibsona.

11 „My dear Mr. Secretary: I hesitate to comply with Mr. Hugh Gibson's suggestion because I think the time has passed when personal intervention on my part or suggestion to foreign politics would be of service, though I am deeply interested in everything that affects Poland and would be willing to do anything that I thought would be effective in assisting her". LC, Bainbridge Colby Papers, Correspondence, 3 A, MayAugust 1920, list prezydenta W. Wilsona do B. Colby'ego z 20 VII 1920 w sprawie apelu posła H. Gibsona. Por. The Papers of Woodrow Wilson, vol. 65: February 28-July 31, 1920, red. A. S. Link, J. E. Little, Princeton 1991, s. 531.

12 „You will bear in mind that the Department's information on many important phases of the situation is fragmentary and conflicting". LC, Bainbridge Colby Papers, Correspondence, 3 A, May-August 1920, list B. Colby'ego do J.W. Davisa, ambasadora w Londynie, 2 VIII 1920. 
jąc nadzieję, że uda się je przekształcić w jak najkrótszym czasie w zasadnicze negocjacje polityczne. Rosja Sowiecka miała powrócić do stołu obrad wielkich mocarstw jako pełnoprawny członek tego elitarnego klubu, by współdecydować o losie swych małych i kłopotliwych sąsiadów z Europy Środkowo-Wschodniej. Na przełomie lipca i sierpnia szukał już tylko pretekstu, by ostatecznie porzucić problem polskiej niepodległości ${ }^{13}$.

Miała mu tego pretekstu dostarczyć polityczna część misji międzyalianckiej, jaka skierowana została do Warszawy 21 lipca, formalnie z gen. Maximem Weygandem i Edgarem d'Abernonem na czele. Najważniejszym wysłannikiem Lloyda George’a był jednak sekretarz i faktyczny organizator prac jego gabinetu, sir Maurice Hankey. Powrócił szybko bo już w pierwszych dniach sierpnia, by dostarczyć obszerny raport premierowi. Część pierwsza tego szokującego swą ignorancją i skrajnie złą wolą (wobec Polski) raportu była publikowana w tomie dokumentów brytyjskiej polityki zagranicznej. Części pozostałe (2. do 5.) publikowane nie były. Powinny być - albowiem rzucają one mocne, nawet jaskrawe, rzec można, światło na tendencje polityki brytyjskiej (jaką reprezentował osobiście premier Lloyd George) wobec zagrożonej niepodległości Polski. W części drugiej Hankey powoływał się na przeprowadzoną w Pradze w drodze do Warszawy rozmowę z prezydentem Czechosłowacji Tomášem Masarykiem, który miał wyrazić w niej całkowite przekonanie o nieuchronności militarnego upadku Polski. W części trzeciej uwagę przykuwa kuriozalny portret Józefa Piłsudskiego, naszkicowany przez jego brytyjskiego gościa (,Jest wysoki, ale garbi się tak bardzo w ramionach, że niemal sprawia wrażenie garbusa. [--] Jego twarz ma trupi wyraz, z głęboko osadzonymi oczami. [--] Jest z pochodzenia Polakiem z Austrii. [- ] Wydaje mi się, że był w więzieniu w Austrii, kiedy wybuchła wojna. Politycznie jest socjalistą. Jeden z wiceministrów powiedział mi, że P.[iłsudski] był przyjacielem Lenina"14 - itd., itp....). Część czwarta zawiera skrajnie pesymistyczne uwagi o sytuacji na froncie. Najważniejsze

${ }^{13}$ Zob. o tym szerzej w: A. Nowak, 21 miesięcy później: Wielka Brytania wobec pierwszego kryzysu polskiej niepodległości (lipiec-sierpień 1920 roku), w: Stan świadomości narodowej Polaków w przededniu niepodległości. Materiały z posiedzenia naukowego zorganizowanego z okazji 90-lecia odzyskania niepodległości w 1918 roku, red. J. Machnik, W. Rojek, Kraków 2010, s. 197-224; idem, Czy mogło nie być II wojny światowej? O tzw. nocie Curzona z 11 lipca 1920 r. i jej (możliwych) konsekwencjach, w: Niepiękny wiek XX, red. B. Brzostek i in., Warszawa 2010, s. 21-46.

${ }^{14}$ "He is tall, but stoops so much about the shoulders as almost to have the appearance of a hunchback. [--] His face is cadaverous with deep-set eyes [--]. He is by origin an Austrian [sic!] Pole [--] I believe he was in prison in Austria [sic!] when the war broke out. Politically he is a Socialist. One of the junior ministers told me that P. had been a friend of Lenin [sic!]", National Archives, Kew (London) (dalej: NA), Cabinet 
są jednak datowane 3 sierpnia (w drodze powrotnej przez Niemcy) uwagi podsumowujące, zawarte w części piątej raportu, które Hankey przedstawił zaraz po przybyciu do Londynu swojemu szefowi. „Trwałe istnienie Polski pomiędzy Niemcami z jednej strony i Rosją z drugiej jest bardzo wątpliwe, nawet jeśli przetrwa ona obecny kryzys" - stwierdzał sekretarz brytyjskiego gabinetu. I wyciągał ostateczne wnioski: „Powinniśmy wycofać się z wszelkich militarnych zobowiązań w Polsce i pozostawić Europę Środkową i Wschodnią, aby ukształtowała swój los bez naszej interwencji [- -].Prawdopodobnie jest już za późno, by użyć Niemcy jako militarną barierę przeciw Rosji. Bardziej dalekowzroczną polityką byłoby [--] użycie Niemiec jako pomostu, po którym z biegiem lat brytyjski kapitał mógłby zostać wprowadzony do Rosji i przywrócone zostałyby normalne stosunki"15. Hankey i całkowicie podzielający jego opinie Lloyd George zakładali, że po nieuchronnym krachu Polski Niemcy powinny stać się nie barierą, ale pomostem, który połączy Europę Zachodnią (w szczególności Wielką Brytanię) z Rosją Sowiecką w odnowicielskiej dla całego kontynentu stabilizacji i wymianie handlowej.

Kwestię reorganizacji systemu wersalskiego po tak wielkich zmianach na wschodzie Lloyd George chciał wziąć pod swoje skrzydła i zwołać w tym celu wielką konferencję do Londynu. Przedstawicieli Rosji Sowieckiej już miał u siebie - i to na najwyższym szczeblu. 4 sierpnia w Londynie była już delegacja z Kamieniewem (członkiem czteroosobowego w owym czasie Biura Politycznego partii bolszewickiej i osobą numer dwa, po Leninie, w państwie sowieckim) oraz Leonidem Krasinem (Leonid Borisovič Krasin) na czele. Lloyd miał nadzieję przekonać Włochy, jak zwykle, do pójścia pod jego przewodem. Idei konferencji zmieniającej system wersalski i dopuszczającej bolszewików do stołu

Papers, 1920, Cab. 21/180, „Mission to Poland - Personal Report by Sir M. Hankey on His Visit to Warsaw", July-August 1920.

15 „The continued existence of Poland between Germany on the one hand and Russia on the other is very problematical, even if she survives the present crisis [--]. We should pull out of all military responsibilities in Poland and leave Central and Eastern Europe to work out its own fate without our intervention [- - ]. It is probably too late to use Germany as a military barrier against Russia. A more far-sighted policy would be to [--] use Germany as the bridge by which in the course of years British capital may be introduced to Russia and normal relations be restored". NA, Cabinet Papers, 1920, Cab. 21/180, „Mission to Poland - Personal Report by Sir M. Hankey on His Visit to Warsaw", July-August 1920. Dodajmy, że w podobny sposób - choć ze znacznie większym współczuciem dla Polski - oceniał możliwość skutków sowieckiego zwycięstwa pod Warszawą głównodowodzący okupacyjnych wojsk amerykańskich w Koblencji gen. Henry Allen w swoim raporcie do sekretarza wojny Newtona Bakera z 10 VIII 1920 - LC, Papers of Newton Baker, Cont. 11, list H. Allena z Koblencji z 10 VIII 1920 do N. Bakera. 
politycznych obrad zdecydowanie niechętna była Francja.Powodzenie planowanego (na „trupie białej Polski”) przez brytyjskiego premiera przedsięwzięcia zależało w niemałym stopniu od postawy Waszyngtonu. Dlatego zaraz po odebraniu raportu Hankey'a Lloyd George zdecydował się napisać 5 sierpnia osobisty list do prezydenta USA, z prośbą o pilne rozważenie możliwości udziału wysokiego przedstawiciela administracji waszyngtońskiej w projektowanej konferencji w Londynie. Głównym argumentem na rzecz nieuchronności takiego rozwiązania miał być dołączony do listu jako obszerny aneks - cytowany wyżej obszernie raport Hankey'a... ${ }^{16}$

Dodajmy przy okazji, że przesyłający list premiera do ambasady w Waszyngtonie Philip Kerr - osobisty sekretarz i najbliższy doradca Lloyda George'a - już wcześniej starał się przygotować przedstawicielstwo brytyjskie w stolicy USA do argumentowania na rzecz nieuchronnie wielkich zmian na europejskim wschodzie. Jeszcze w pierwszej połowie czerwca pisał do brytyjskiego ambasadora w Waszyngtonuie Aucklanda Geddesa z irytacją, że znakomicie rozwijającym się negocjacjom z bolszewicką delegacją w Londynie przeszkadza teraz "ta absurdalna polska ofensywa” (,this absurd Polish offensive”), i komentował zgryźliwie, że to wyraz odwiecznej, fatalnej polskiej polityki „nadymania się, aż pękną” („their traditional policy of inflating themselves until they bust"). Wieszczył jednak $\mathrm{z}$ absolutnym przekonaniem, iż załamanie Polski jest już bliskie. W kolejnym liście do Geddesa, wysyłanym już 5 lipca z konferencji w Spa (gdzie kilka dni później to właśnie Kerr narysuje słynną do dziś tzw. linię Curzona $)^{17}$, padły ważne słowa, które miały za pośrednictwem brytyjskiego ambasadora tłumaczyć w Waszyngtonie brytyjski punkt widzenia na bolszewicko-polski kryzys w europejskiej polityce:

Jak pan wie, premier próbował przez długi czas przecierać drogę dla układu z Rosją, częściowo dlatego, iż uznaje, że żywność oraz surowce z Rosji są konieczne dla odbudowy Europy, a częściowo dlatego, że uznaje, iż pokój w Europie Wschodniej jest konieczny dla świata, częściowo wreszcie dlatego, że jest przekonany, iż najkrótszą drogą do

${ }^{16}$ Zob. tekst listu Lloyda George'a z 5 VIII do prezydenta Wilsona: The Papers of Woodrow Wilson, vol. 66: August 2-December 23, 1920, red. A. S. Link, J.E. Little, Princeton 1992, s. 46-47; por. list Philipa Kerra, osobistego sekretarza i najbliższego doradcy Lloyda George'a, do brytyjskiego ambasadora w Waszyngtonie, Aucklanda Geddesa, z 5 VIII 1920, z prośbą o przekazanie osobistego listu premiera Wilsonowi - National Archives of Scotland, Edynburg (dalej: NAS), Philip Kerr Papers, GD 40/17/1402; LC, Bainbridge Colby Papers, Correspondence, 3 A, May-August 1920, list B. Colby'ego do prezydenta z 18 VIII 1920, przekazujący odebraną z ambasady brytyjskiej przesyłkę z listem Lloyda George'a z 5 VIII.

${ }^{17}$ Zob. A. Nowak, Czy mogło nie być II wojny światowej?, s. 21-46. 
zabicia bolszewizmu jest zakończenie wojny i danie rosyjskiemu ludowi szansy odnowienia normalnych stosunków gospodarczych i dopuszczenia na nowo zachodnich wpływów do Rosji. [--] Sytuację ogromnie skomplikował polski kryzys. Polakom, tak jak to wszyscy przewidywali, nie udało się ich ofensywą zmiażdżyć bolszewików. Tylko wyczerpali się sami. W międzyczasie bolszewicy odpowiedzieli zbrojnie i wydaje się, że osiągną zwycięstwo nad polską armią. Co się stanie, kiedy dostaną się do Warszawy - nikt nie wie. Powinniśmy jakoś ratować Polskę, teraz jednak muszą oni [Polacy] zebrać żniwo imperialistycznej polityki, jaką prowadzili. W każdym razie jednak, uważam za niewątpliwe, że dryfujemy w kierunku jakiegoś [nowego] układu w Europie Wschodniej. Konwulsje mogą trwać jeszcze miesiąc czy dwa, ale samo wyczerpanie, zarówno mentalne, jak i fizyczne, nieuchronnie doprowadzi do uspokojenia [appeasement] w Europie Wschodniej, a kiedy uspokoi się Europa Wschodnia, sądzę, że Zachód uspokoi się także $e^{18}$.

Pozostawało tylko wyjaśnić, co to znaczy „jakoś uratować Polskę” - czy nie np. poprzez uznanie jej jako autonomicznej republiki sowieckiej a także, co w tym krytycznym kontekście znaczy tak później znamienne słowo appeasement...

Sam Lloyd George w swoim liście do prezydenta Wilsona z 5 sierpnia był nie mniej wymowny, dodając w pewnym sensie wyjaśnienie do intrygującej kwestii owego „appeasementu”, jaki wyobrażano sobie w Londynie późnym latem 1920 r. Najpierw usprawiedliwiał swoją decyzję o faktycznym porzuceniu Polski: „Polacy są wcieleniem perwersyjnej nieudolności. To jakby próbować ratować tonącego człowieka, który robi wszystkie głu-

${ }^{18}$ „As you know the P.M. has been trying for a long time to pave the way for a settlement with Russia, partly because he thinks that food and raw materials from Russia are necessary for the reconstruction of Europe, partly because he thinks that peace in Eastern Europe is necessary to the world, and partly because he is sure that the quickest way to killing Bolshevism is to put an end to war, and to give the Russian people a chance of resuming normal business and let Western influences once more into Russia. [- - The situation is greatly complicated by the Polish crisis. The Poles, as everybody predicted, have not succeeded in smashing the Bolsheviks by their offensive. They have only exhausted themselves. Meanwhile the Bolsheviks have retaliated and look like achieving victory over the Polish army. What will happen if they get to Warsaw nobody quite knows. We shall have to save Poland somehow, but for the moment they must reap the harvest of the imperialist policy they have pursued. In any case, however, I think there is little doubt that we are drifting towards a settlement in Eastern Europe. There might be another final month or two of convulsion, but sheer exhaustion, both mental and physical, is bound to bring a general appeasement in Eastern Europe, and as Eastern Europe settles down I think the West will settle down too". NAS, Philip Kerr Papers, GD 40/17/1397, list P. Kerra ze Spa do A. Geddesa w Waszyngtonie, 5 VII 1920. Wcześniejsze mikrocytaty w tymże akapicie pochodzą z listu Kerra do Geddesa z 11 VI 1920 - ibidem, GD 40/17/1395. 
pie rzeczy, których nie powinien i nie robi nic z tego, o co się go błaga"19. Pytał jednak przede wszystkim, czy kiedy dojdzie do konferencji między Rosją Sowiecką a przedstawicielami Ententy (spodziewał się, że nastąpi to na jesieni), Waszyngton zechce przysłać na nią swoich reprezentantów. Naturalnie, aby przekonać prezydenta Wilsona (a także Francję, jak również konserwatywną większość swego własnego gabinetu) do zgody na zasadnicze rokowania polityczne z Rosją Sowiecką, Lloyd George potrzebował choćby pozorów dobrej woli ze strony Moskwy, choćby pozorów zachowania polskiej odrębności po najeździe Armii Czerwonej. Przekonywał, że jest na to poważna szansa, choć nie tłumaczył dokładniej, jak sobie wyobraża jej realizację, gdyż to mogłoby jednak zrazić amerykańskiego prezydenta. Ostatecznie intencje brytyjskiego premiera zostały ujawnione w tygodniu między 4 a 10 sierpnia.

4 sierpnia, w przeddzień wysłania listu Lloyda George'a do Wilsona, londyński „Times”, najbardziej opiniotwórczy dziennik polityczny ówczesnego świata, opublikował wiadomość o powstaniu w Białymstoku Tymczasowego Komitetu Rewolucyjnego Polski z Julianem Marchlewskim i Feliksem Dzierżyńskim na czele. Udawać, że Moskwie nie chodzi o sowietyzację Polski, było coraz trudniej. Lloyd George jednak nie rezygnował bynajmniej. Nie czekając na odpowiedź z Waszyngtonu, starał się zmusić jak najszybciej stronę polską do podjęcia bilateralnych rokowań pokojowych z Rosją Sowiecką, a w każdym razie wykazać, że strona sowiecka nie odpowiada za ich odwlekanie - a zatem nie ponosi winy za przedłużanie wojny z Polską. Wydawało się, że granicę możliwości tej gry wytyczało ewentualne zdobycie Warszawy przez Armię Czerwoną w takiej sytuacji trudno byłoby już wykazać Francji, a nawet znacznej części własnej, brytyjskiej opinii publicznej, że prowadzona kosztem Polski polityka appeasementu wobec Rosji Sowieckiej jest właściwa. Brytyjski premier przygotowywał się jednak do przekroczenia i tej granicy, uznając, że zajęcie Warszawy jest praktycznie nieuniknione i trzeba raczej skoncentrować się z góry na zminimalizowaniu wynikających z takiego obrotu sprawy możliwych negatywnych dla „europejskiego porządku” konsekwencji.

Strona sowiecka gotowa była grać w tę grę, w każdym razie takie zadanie miała sowiecka delegacja wysłana do Londynu z Kamieniewem i Krasinem na czele. 4 sierpnia, niemal natychmiast po przywiezieniu sowieckiej delegacji brytyjskim niszczycielem z Rewla do Londynu,

19 „The Poles are the embodiment of perverse inefficiency. It is like trying to save a drowning man who does all the silly things he is wanted not to do and does nothing he is begged to do". Cyt. za: The Papers of Woodrow Wilson, vol. 66, s. 46. 
Lloyd George zaprosił Kamieniewa i Krasina na Downing Street. Premiera wspierał już w tej rozmowie Hankey, który dopiero co wrócił ze swej misji w Warszawie, autor „noty Curzona” z 11 lipca, Kerr, a także doradca ekonomiczny premiera - Edmund F. Wise (autor raportu z początku 1920 r., który uzasadniał konieczność nawiązania stosunków z Rosją Sowiecką względami ekonomicznymi głodującej Europy) oraz - z urzę$\mathrm{du}$ - lider konserwatywnej większości parlamentarnego zaplecza rządu, Andrew Bonar Law. Sekretarz War Office, Winston Churchill, został za drzwiami, podobnie jak formalny kierownik Foreign Office, lord George Nathaniel Curzon - i ta sytuacja, a ściślej specyficzny skład wybranych przez premiera uczestników (poza Lawem) rozmów z sowiecką delegacją ukazuje dobitnie, jakie było nastawienie brytyjskiej polityki wobec kryzysu polskiej niepodległości i kto faktycznie tę politykę prowadził. Lloyd George zaapelował do Kamieniewa, by ten dostarczył jakichś dowodów dobrej woli strony sowieckiej w sprawie Polski, w innym bowiem wypadku Wielka Brytania będzie musiała wypełnić zobowiązania przyjęte w rozmowach z Francją - i ogłosić blokadę morską Rosji. Obiecał jednak nie ujawniać tej groźby, aby ułatwić stronie sowieckiej pozytywną odpowiedź na swoją prośbę ${ }^{20}$.

Kulminacyjny moment gry brytyjskiego premiera nadszedł 10 sierpnia. Zaczął ten dzień od spotkania z kierującym związkowymi protestami przeciwko udzielaniu Polsce jakiejkolwiek pomocy, Ernestem Bevinem (późniejszym, w latach 1945-1951, ministrem spraw zagranicznych). Występujący w roli rzecznika delegacji tzw. Council of Action, Bevin postawił sprawę jasno: występujemy nie tylko przeciw zaangażowaniu Wielkiej Brytanii w nową wojnę, ale przeciwko wszelkiej pomocy dla krajów, które walczą z Rosją Sowiecką. Uzasadniał tę postawę nie żadną ideologiczną sympatią dla bolszewizmu, ale - jak to określił - typowo angielskim poczuciem fair play: to Polska napadła, stwierdzał, Rosję i stało się to w wyniku „spisku ciemnych sił”. Lloyd George upewnił się, czy jednak jeśli Rosja Sowiecka zrobi Polsce to, co Rosja carska - czyli pozbawi ją niepodległości - czy wówczas wolno będzie rządowi brytyjskiemu posłać choćby parę butów walczącym o niepodległość Polakom, czy też związki zastrajkują nawet w takiej sytuacji. Bevin odpowiedział, że taka sytuacja nie nastąiła. Zadał z kolei sam charakterystyczne pytanie premierowi: co zrobiłby, ,zakładając, że polski lud sam zgodzi się na konstytucję, któ-

${ }^{20}$ Stenogramy rozmów brytyjsko-sowieckich z 4 sierpnia $1920 \mathrm{r}$. w Londynie są opublikowane w: Documents on British Foreign Policy 1919-1939, red. R. Butler, J.P. T. Bury, First series, t. 8, London 1958, s. 669-680; por. także analizę tych rozmów w: R. Ullman, R.H. Ullman, Anglo-Soviet Relations, 1917-1921, t. 3: The Anglo-Soviet Accord, Princeton 1972, s. $185-210$. 
ra nie odpowiadałaby mocarstwom alianckim” (,supposing the Polish people themselves agreed upon a Constitution which did not suit the Allied Powers”)? Odpowiedź premiera była równie charakterystyczna: „Nie obchodzi mnie, jaka to jest konstytucja. Jak chcą mieć u siebie Mikado, to jest ich sprawa"21. Sens pytania sprowadzał się do tego, czy rząd brytyjski będzie się sprzeciwiał, jeśli czerwona flaga zawiśnie nad Warszawą przy zachowaniu wszelkich pozorów, iż zawiesiły ją polskie ręce. Odpowiedź Lloyda George'a sprowadzała się do stwierdzenia, że w takim wypadku Londyn z ulgą powstrzyma się od wszelkiej interwencji.

Występując następnie przed Izbą Gmin z wyjaśnieniem polityki swego rządu w sprawie polskiego kryzysu, Lloyd George wyłożył dalej rolę mocarstw zachodnich: „Alianci powinni doradzać Polakom, żeby podjęli starania o wynegocjowanie rozejmu i zawarcie pokoju, o ile tylko niepodległość etnograficznej Polski zostanie uznana"22. Gdyby Polacy takie warunki odrzucili, wtedy - stawiał kropkę nad „," brytyjski premier - „alianci nie mogliby poprzeć Polski” (,the Allies could not support Poland”).

W tym dramatycznym momencie członek Biura Politycznego partii bolszewików i zastępca Lenina w Radzie Komisarzy Ludowych, Kamieniew, przysłuchujący się całej debacie z fotela w Distinguished Strangers Gallery, dał znak jednemu ze współdziałających z nim posłów Labour Party, by ten doręczył premierowi zapieczętowany pakiet $z$ jego listem. List ten zawierał odpowiedź na zasadnicze pytanie: jakie są sowieckie warunki dla polskiej delegacji pokojowej, skierowanej na rozmowy do Mińska? Lloyd George zwołał w trybie natychmiastowym kadłubowe posiedzenie swojego gabinetu, w gmachu parlamentu, by rozważyć owe warunki. List Kamieniewa wymieniał m.in. konieczność demobilizacji polskiej armii do poziomu dziesięciotysięcznej kadry, wzmocnionej przez 50 tys. poborowych; polska armia powinna natychmiast wycofać się 50 wiorst (czyli mniej więcej $50 \mathrm{~km}$ ) na wschód od aktualnej linii frontu (Warszawa znalazłaby się w ten sposób na granicy sowieckiej okupacji wojskowej); cała broń polska miała być wydana stronie sowieckiej oraz - nie wymienionej nigdzie indziej w nocie Kamieniewa - „obywatelskiej milicji” (czyli, de facto, polskiej Armii Czerwonej). Mimo sprzeciwu niektórych kolegów ze swego gabinetu, zwracających uwagę na niepokojące szczegóły, takie zwłaszcza jak zapowiedź faktycznej likwidacji Wojska Polskiego przy jednoczesnym powołaniu bliżej

21 „I do not care what the Constitution is. If they like to have a Mikado there, that is their business”. Cyt. za: Council of Action at Downing Street, ,Times”, 11 VIII 1920, s. 12.

22 „The Allies should advise Poland to endeavour to negotiate an armistice and to make peace as long as the independence of ethnographic Poland is recognized". Wystąpienie Lloyda George'a cytuję za: Parliamentary Debates, 5th Series, House of Commons, [London] vol. 133, kol. 254-272; por. House of Commons, „Times”, 11 VIII 1920, s. 12. 
nieokreślonej „milicji obywatelskiej”, Lloyd George stwierdził, iż „warunki [ogłoszone w liście Kamieniewa] nie były nawet w przybliżeniu tak surowe jak te, które alianci narzucili Niemcom i Austrii, i że on [premier] nie uważa, aby Brytania mogła rozpoczynać wojnę, żeby uzyskać [dla Polski] warunki lepsze od tych"23.

W tym duchu premier postanowił poinformować polski rząd za pośrednictwem posła brytyjskiego w Warszawie, iż Rząd Jego Królewskiej Mości rekomenduje przyjęcie warunków sowieckich, ich odrzucenie zaś przez Warszawę uzna za powód do zwolnienia Wielkiej Brytanii z wszelkich zobowiązań do pomocy Polsce. Zdając sobie jednocześnie sprawę z tego, że Paryż z pewnością nie podzieli tej interpretacji sowieckich warunków, ani też wynikającego z nich stanowiska brytyjskiego, Lloyd George zdecydował się na krok zdumiewający: zaproponował, by nie informować Francji o tym stanowisku. Uzasadnienie tego kroku, przedstawione przez brytyjskiego premiera jego kolegom z gabinetu, warto przytoczyć: „Jeśli te warunki zostałyby zakomunikowane Paryżowi, było niebezpieczeństwo, że mogłyby zostać odrzucone przez rząd francuski. [--] Francja była wściekle antybolszewicka, a Francuzi mieli już kiedyś doświadczenie, czym jest komunizm. Obecna sprawa nie ma jednak nic wspólnego z komunizmem"24. A zatem najazd Armii Czerwonej na Polskę nie miał nic wspólnego z komunizmem... W ten sposób 10 sierpnia Lloyd George, praktycznie rzecz biorąc, określił oficjalną pozycję rządu brytyjskiego wobec polskiego kryzysu: sprowadzała się ona do akceptacji sowieckich warunków dla Warszawy.

Dokładnie w tym samym dniu swoje stanowisko wobec ,polskiego kryzysu" sformułował wreszcie także Waszyngton, w postaci oficjalnej noty sekretarza stanu, Colby'ego. Bezpośrednią pobudką do jej wydania była prośba rządu włoskiego, przekazana przez ambasadę w Waszyngtonie, by Ameryka określiła jednoznacznie swój pogląd w kwestii: co robić wobec sowieckiej inwazji do centrum Europy? Ratować Polskę, a w każdym razie

${ }^{23}$ „the terms were not nearly so severe as had been imposed by the Allies upon Germany and Austria, and he did not think that Britain could make war in order to secure better conditions than these”. NA, Cab. 23/22 (7 VII-28 X 1920), „Minutes of a Conference of Ministers held at the House of Commons, 10 August, 1920"; zob. także Parliamentary Debates, 5th Series, House of Commons, vol. 133, kol.271-272; por. House of Commons, „Times”, 11 VIII 1920, s. 12.

${ }^{24}$ "If the terms were communicated to Paris there was the danger that they would be negatived by the French Government. [--] France was passionately anti-bolshevist, and the French had had experience of communism. The present case had, however, nothing to do with communism”. NA, Cab. 23/22 (7 VII-28 X 1920), „Minutes of a Conference of Ministers held at the House of Commons, 10 August, 1920"; zob. także Parliamentary Debates, 5th Series, House of Commons, vol. 133, kol. 271-272; por. House of Commons, „Times”, 11 VIII 1920, s. 12. 
próbować stawić opór bolszewikom - jak podpowiadała Francja? Czy raczej podjąć rozmowy z Kamieniewem w Londynie, jak to już zaczął robić brytyjski premier? Odpowiedź Waszyngtonu w tym dramatycznym momencie mogła mieć zasadnicze znaczenie. Nie tylko dla Włoch ${ }^{25}$.

W opracowaniu noty Colby'ego największy udział miał wspomniany sympatyk socjalizmu, Spargo, którego memorandum, przesłane sekretarzowi stanu 31 lipca, stało się faktycznie podstawą rządowego dokumentu. Pewien wkład miał także John Allyne Gade, rezydujący w Rydze nieoficjalny przedstawiciel amerykański w nowo utworzonych (i nie uznawanych przez USA) republikach nadbałtyckich. Podkreślał on konieczność wymienienia Finlandii jako drugiego i jedynego obok Polski kraju z obszarów Imperium Rosyjskiego, który powinien mieć potwierdzone przez Amerykę prawo do niepodległości ${ }^{26}$. Swoje uwagi wniósł również podsekretarz stanu, N.H. Davis, który podkreślił dwa główne cele przygotowywanego dokumentu: „Wydaje mi się, że powinniśmy naciskać na utrzymanie integralności Polski, a po drugie - integralności Rosji" ${ }^{27}$.

Rosja oczywiście jest najważniejsza. Polska - jeśli tylko wykroczy poza linię Bugu (wskazaną przez sprzymierzone mocarstwa w grudniu 1919 r. jako właściwa, tymczasowa granica Polski - dopóki nie odrodzi się demokratyczna Rosja i w bezpośrednim układzie z Warszawą nie ustali ostatecznego kształtu tej granicy) - podpada faktycznie pod najcięższy zarzut imperializmu. Zauważmy, że nie Rosja w granicach z 1914 r. jest imperialistyczna, nie Stany Zjednoczone, kolonizujące faktycznie od 1898 r. Kubę i Filipiny - ale Polska, wykraczająca poza linię Bugu... A imperializm (polski w tym przypadku) jest głównym winowajcą odpowiedzialnym za trwanie bolszewizmu. „Nasz pogląd jest taki, że imperializm raczej ożywia, aniżeli niszczy sowiecki reżim, rząd amerykański zaś, który jest kolebką demokracji, musi użyć wszelkich

${ }^{25}$ Zob. LC, Bainbridge Colby Papers, Correspondence, 3 A, May-August 1920, informacja podsekretarza stanu, N. H. Davisa z 5 VIII 1920 o rozmowie z sekretarzem ambasady Włoch; por. D. M. Smith, Aftermath of War. Bainbridge Colby and Wilsonian Diplomacy 1920-1921, Philadelphia 1970, s. 64-70. Najlepszym, zwięzłym opracowaniem rosyjskiego kierunku w polityce zagranicznej Włoch w 1920 r. wydaje się monografia: G. Petracchi, Da San Pietroburgo a Mosca. La diplomazia italiana in Russia 1861/1941, Roma 1993, s. 255-290.

${ }^{26}$ LC, Bainbridge Colby Papers, Correspondence, 3 A, May-August 1920, list J. Spargo do B. Colby'ego z 31 VII 1920 wraz z załączonym memoriałem o stosunku do Rosji, bolszewizmu i „kryzysu polskiego”, a także list J. Spargo do J. Allyne’a Gade'a z 3 VIII 1920, w którym nadawca potwierdza, że przedłożył właśnie sekretarzowi stanu „a draft of a statement" - w sprawie Rosji.

27 „It seems to me that we should stress on the maintenance of the integrity of Poland, and second, the integrity of Russia". LC, Bainbridge Colby Papers, Correspondence, 3 A, May-August 1920, list N.H. Davisa do B. Colby'ego, 7 VIII 1920. 
możliwych, sprawiedliwych i praktycznych środków, żeby ocalić demokrację przed upadkiem pod naciskiem bolszewizmu czy też w walce między bolszewizmem i imperializmem"28.

Oparta na tych przesłankach nota została ostatecznie skompilowana przez Colby'ego. Miała wyrazić poparcie dla niepodległości Polski, nie zostawiając żadnej wątpliwości, że sowietyzacja tę niepodległość likwiduje. Przede wszystkim jednak miała wyrazić sprzeciw wobec polityki „rozczłonkowania Rosji” („dismemberment of Russia”) - czyli odrywania od państwa rosyjskiego w jego przedrewolucyjnych granicach terytoriów narodowych, poza Polską i Finlandią. Wbrew nadziejom Lloyda George'a stanowisko Waszyngtonu pozostało nieugięte wobec bolszewików. Rząd amerykański nie uznawał ich za reprezentantów Rosji, w jego ocenie byli oni poważnym zagrożeniem dla pokoju i porządku. Oparta tylko na przemocy władza bolszewików nie jest demokratyczna i Stany Zjednoczone, uznając zdobycze i wartości rewolucji rosyjskiej 1917 r., powinny pomóc Rosji w ustanowieniu prawdziwej demokratycznej reprezentacji. Problem jednak polegał na tym, że nota nie wskazywała, na czym taka pomoc mogłaby konkretnie polegać, a co więcej - nie mówiła nic o tym, co rząd amerykański zrobi, jeśli Rosja Sowiecka jednak podbije Polskę (a przecież 10 sierpnia Armia Czerwona była już pod Warszawą). Sam Colby, przesyłając 9 sierpnia sygnowaną przez siebie notę do akceptacji prezydentowi, stwierdzał to z pokorą: „Drogi Panie Prezydencie. Załączony szkic noty w sprawie polskiej sytuacji ma jedną oczywistą słabość. Nie da się powiedzieć, co zrobimy [podkreślenie w oryginale - A. N.], jeśli w ogóle cokolwiek zrobimy. Jest też [nota] dosyć długa, ale jest powód, by powiedzieć niemal wszystko to, co ona zawiera. Mam nadzieję, że nie uzna jej Pan za całkowicie nieadekwatną" ${ }^{29}$. Prezydent przeczytał notę i zostawił

${ }^{28}$ "Our view is also that imperialism fosters rather than destroys the Soviet regime and the American Government which is the cradle of democracy must use every possible just and practicable means for preventing democracy from falling under the onrush of Bolshevism or under the struggle between Bolshevism and imperialism". LC, Bainbridge Colby Papers, Correspondence, 3 A, May-August 1920, list N. H. Davisa do B. Colby'ego, 7 VIII 1920.

${ }^{29}$ „My dear Mr. President: The enclosed draft of a Note on the Polish situation has certainly one outstanding weakness. It is impossible to say what we will do [podkreślenie w oryginale - A.N.], if anything. It is also pretty long, but there is a reason for saying almost everything that it contains. I hope you will not find it altogether inadequate". LC, Bainbridge Colby Papers, Correspondence, 3 A, May-August 1920, list B. Colby'ego do prezydenta W. Wilsona, 9 VIII 1920. Pełny tekst samej noty z 10 sierpnia: Secretary of State to the Italian Ambassador (hr. Avezzano), w: Papers Relating to the Foreign Relations of the United States, 1920, vol. 3, Washington, D.C. 1936, s. 463-468; por. analizę noty w kontekście polskich stosunków z USA w owym czasie: B. Winid, op. cit., s. 64-72. 
na niej odręczny dopisek. Krótki, wyrażający jeszcze dobitniej bezradność Ameryki w tym momencie: „Dziękuję. To [nota] wydaje mi się doskonałe i wystarczające. WW [Woodrow Wilson]"30.

Wydana oficjalnie 10 sierpnia nota była oczywiście sprzeczna $\mathrm{z}$ intencjami Lloyda George'a, choć - jako deklaracja absolutnej bierności Stanów Zjednoczonych wobec realnej akcji sowieckiej nad Wisłą - nie przeszkadzała mu bardzo. Wszystko realnie zależało teraz od rezultatu bezpośredniej walki żołnierzy polskich z sowieckimi pod Warszawą. Brytyjski premier przekazał im faktycznie komunikat, żeby się poddali. Amerykański sekretarz stanu, z błogosławieństwem prezydenta, miał im do zaoferowania protest przeciw bolszewizmowi, ale i przeciwko ewentualnemu wznowieniu polskiego ,imperializmu”. Wręcz groteskowo wygląda próba interpretacji noty Colby'ego przez niektórych współczesnych historyków jako prefiguracji amerykańskiej doktryny powstrzymywania. „To właśnie tutaj zainaugurowana została ta polityka, która później stanie się znana jako containment" - napisał najnowszy badacz sylwetki Spargo i polityki amerykańskiej tego czasu ${ }^{31}$. Ameryka przecież nie zobowiązywała się, potępiając słownie sowiecką agresję, do żadnej militarnej akcji, ani nawet do jakiegokolwiek materialnego wsparcia ofiary czy potencjalnych kolejnych ofiar. Wręcz przeciwnie: Ameryka deklarowała swoją bezradność, tak jak to doskonale ujął sam Colby w przytoczonym wyżej liście do prezydenta Wilsona.

Może nawet nie bezradność, a raczej świadomie (ale czy mądrze?) wybrana bezczynność. Jaskrawym potwierdzeniem tej świadomej bezczynności było zachowanie prezydenta wobec problemu ewentualnego udziału amerykańskiego okrętu w próbie odblokowania przeładunku towarów dla Polski w gdańskim porcie w końcu sierpnia. Niemieccy dokerzy odmawiali spełniania swoich obowiązków, chcąc zablokować w Wolnym Mieście, wbrew jego statusowi, dostawy towarów dla walczącej z bolszewikami Polski. Francja i Wielka Brytania (głównie z inicjatywy francuskiego premiera, Alexandre'a Milleranda) starały się doprowadzić do odblokowania portu. Poszukiwanie wsparcia w tej akcji ze strony Waszyngtonu zmusiło Colby'ego znów do decyzji. Formalnego udziału w akcji aliantów odmówił, powołując się na odrzucenie ratyfikacji traktatu wersalskiego przez Senat. Zgodził się jednak, wspólnie z Departamentem Marynarki, na wysłanie do Gdańska amerykańskiego okrętu - dla ochrony amerykańskich obywateli

30 „Thank you. This seems to me excellent and sufficient. W.W.”, LC, Bainbridge Colby Papers, Correspondence, 3 A, May-August 1920, list B. Colby'ego do prezydenta W. Wilsona, 9 VIII 1920.

31 „It was here that the policy that came later to be known as containment was actually launched". M. Ruotsila, John Spargo and American Socialism, London 2006, s. 116. 
w Wolnym Mieście. Kiedy dowiedział się o tym prezydent Wilson wpadł w furię: żadnych okrętów nie wolno wysyłać! Kiedy tłumaczył się przed nim sekretarz Departamentu Marynarki, Josephus Daniels, prezydent nazwał inicjatorów tego nieuzgodnionego z nim posunięcia krótko: „szczury” („rats”). Colby musiał bardzo przepraszać swego zwierzchnika. Żaden amerykański okręt nie popłynął do Gdańska, nie wsparł nawet w taki symboliczny sposób walczącej z bolszewikami Polski ${ }^{32}$.

Colby nie miał natomiast żadnych problemów z udzieleniem pełnego wsparcia, także finansowego, akcji zaproponowanej przez Spargo. Była ona jedyną praktyczną kontynuacją noty z 10 sierpnia, a raczej jeszcze jednym potwierdzeniem postawy wystudiowanej bezczynności, jaką przyjął wobec sowieckiego wyzwania Waszyngton ${ }^{33}$. Spargo, wspólnie z Bachmietiewem, wymyślili niezwykle skomplikowaną i zarazem szokująco naiwną intrygę. Jeszcze bardziej szokujące jest jednak to, że autoryzował ją Departament Stanu. Spargo miał udać się do Europy i użyć premiera Szwecji, socjaldemokratę Hjalmara Brantinga, jako „słupa ogłoszeniowego" swojej idei. Polegała ona na wydaniu - podpisanego przez Brantinga, a napisanego przez Spargo i zaakceptowanego przez Colby'ego - apelu do rządu sowieckiego, a także rządów Wielkiej Brytanii, Francji, Włoch, Japonii, itd., niejako w imieniu „,ałej postępowej ludzkości". Byłby to apel - moralna presja na rząd bolszewików, żeby oddali władzę lub zrezygnowali z przymusu w jej stosowaniu i zwołali na nowo Konstytuantę (rozpędzone w styczniu 1918 r. przez tych samych bolszewików Uczrieditielnoje sobranije [Učreditel'noe sobranie] - Zgromadzenie Ustawodawcze, zdominowane przez eserów: socjalistów-rewolucjonistów). Bolszewicy mieli uwolnić więźniów politycznych i zdemobilizować Armię Czerwoną. Warunki planowanego apelu, jak widać, były podobnie niekorzystne dla bolszewików jak te, które oni sami chcieli podyktować kilka tygodni wcześniej w Warszawie. Różnica była taka, że za warunkami sowieckimi dla Polski stała siła szturmującej właśnie nadwiślańską stolicę Armii Czerwonej, za apelem zaś Colby’ego-Spargo-Brantinga stać miała tylko... moralna siła auto-

32 Incydent omawia seria dokumentów w: Papers Relating to the Foreign Relations of the United States, 1920, vol. 3, s. 393-396, a także D. M. Smith, op. cit., s. 72.

${ }^{33}$ Może nie całkiem jedynym, gdyż po nocie Colby'ego z 10 sierpnia jeszcze jednym śladem praktycznej reakcji Departamentu Stanu na agresję sowiecką na Polskę jest wystosowana 21 sierpnia stanowcza nota do rządu Polski, by zrezygnował z ekspansji kosztem Rosji... (sic! - Armia Czerwona była jeszcze wciąż na zachód od Bugu). Jak to ujęto w komunikacie dla prasy amerykańskiej, w sprawie tej noty zobowiązano Polskę „to abstain from any territorial aggression against Russia”. LC, Bainbridge Colby Papers, Correspondence, 3 A, May-August 1920: „For the Press, August $25,1920(\# 2)$ ". 
rów. W zamian za przyjęcie tych warunków świat miał zagwarantować wszystkie zdobycze „rewolucji społecznej” i wesprzeć ekonomicznie nowy rząd powołany przez Konstytuantę. Kiedy bolszewicy przyjmą te warunki - alianci przyrzekną nie atakować nigdy Rosji i zdjąć blokadę. Przyrzekną jednocześnie, że nie udzielą żadnego wsparcia monarchistom rosyjskim. Spargo liczył, że apel poprą socjaliści całej Europy - i to pozwoli wesprzeć istotnie socjalistów rosyjskich, którzy zachęceni w ten sposób obalą bolszewików. We wrześniu, pod drodze do Sztokholmu, Spargo spotkał się z nestorem chłopskich socjalistów rosyjskich, Nikołajem Czajkowskim (Nikolaj Vasil'evič Čajkovskij), z ostatnim ambasadorem Rosji republikańskiej w Paryżu, Wasilijem Makłakowem (Vasilij Alekseevič Maklakov), z kierownikiem spraw zagranicznych rządu gen. Piotra Wrangla, Piotrem Struve. Przeprowadzone wreszcie w końcu miesiąca bezpośrednie rozmowy z premierem Brantingiem zakończyły się nieuchronnym fiaskiem. Po konsultacji z rządem Branting odrzucił plan Spargo jako „stanowczo zbyt amerykański"... Uparty autor utopijnego projektu liczył jeszcze, że może holenderski socjalista Emil Vandervelde wystąpi zamiast Brantinga - ale także i w tym przypadku musiał pogodzić się z porażką ${ }^{34}$.

Prezydent Wilson uzyskał jesienią 1920 r. pokojową Nagrodę Nobla za swe niewątpliwe zasługi w roku pokojowej konferencji paryskiej. Pokój, ustanowiony w czerwcu 1919 r., pozostał jednak niedokończony. O tym, że jednak, przynajmniej na 19 lat, zapanował na terenach na wschód od Niemiec, zadecydowali nie D. Lloyd George, nie W. Wilson, ani apele socjalistów z Ameryki, Szwecji czy Holandii, ale żołnierze walczący pod Warszawą i nad Niemnem w sierpniu-wrześniu 1920 r., a potem - w Rydze dyplomaci polscy i sowieccy (a ściślej, ich mocodawcy).

Smutnym podsumowaniem tej bezradności, jaką wykazały na dwa różne sposoby mocarstwa anglosaskie wobec sowieckiego wyzwania, są dwa listy.Zacytujmy najpierw ten, który wysłał wciąż częściowo sparaliżowany, rozgoryczony prezydent USA. Wilson odpowiedział na list brytyjskiego premiera z 5 sierpnia dopiero 3 listopada, dzień po przegranych przez kandydata jego partii - Demokratów - wyborach prezydenckich. Pisał z melancholią o powracającym wciąż w niepojęty sposób zagrożeniu wojną. Dla

${ }^{34}$ LC, Bainbridge Colby Papers, Correspondence, 3 A, May-August 1920, „A rough memo copy, ca. Summer 1920" [projekt apelu Spargo z sierpnia 1920]; maszynopisowa wersja apelu: „To the Russian Socialist Federal Soviet...”; list J. Spargo do B. Colby'ego z 25 VIII 1920 (omawiający szczegóły wykonania projektu po przybyciu do Europy, a przed spotkaniem z Brantingiem); LC, Bainbridge Colby Papers, Correspondence, 3 B, September-December 1920, list B. Colby'ego do J. Spargo z podziękowaniem (i czekiem na 2,5 tys. dolarów) za dotychczasowe usługi; por. M. Ruotsila, op. cit., s. 118-121 (autor mylnie interpretuje projekt apelu, tak jakby jego adresatem miał być prezydent Wilson). 
spraw Rosji, bolszewizmu i Polski znalazł miejsce po omówieniu kwestii Albanii. Dołączał się do słów krytyki brytyjskiego premiera pod adresem Polaków za ich nieroztropny entuzjazm i terytorialne ambicje: „Wierzę, że zasadniczo zgadzamy się co do szaleństwa Polaków. Obawiałem się, że ich entuzjazm, jaki nastąpił po [ich] chwilowych sukcesach militarnych, może doprowadzić do nalegania [z ich strony] na terytorialne układy, które staną się źródłem przyszłych problemów". Nie zmienił także swego doskonale biernego stanowiska wobec bolszewizmu: „Co do Rosji, to nie mogę oprzeć się wrażeniu, że bolszewizm sam by się wypalił, gdyby go tylko zostawić w spokoju"35.

Bolszewizm nie wypalił się, choć od jesieni 1920 r. żaden z sąsiadów ani żadne z mocarstw nie niepokoiło władzy sowieckiej - aż do 22 czerwca 1941 r. W tym czasie jednak to bolszewizm, zwycięski w Rosji, miał jak najbardziej „niepokoić” swoich mniejszych europejskich sąsiadów, w tym uznawane przez Waszyngton już w roku 1920 państwa, takie jak Finlandia, Polska czy Rumunia. Ta ewentualność jednak najwyraźniej nie nawiedzała wyobraźni amerykańskiego prezydenta jako poważny problem. Był gotów czekać, aż bolszewizm wypali się sam.

Wielka Brytania, która próbowała poradzić sobie z tym problemem inaczej - nie biernością, ale od razu porozumieniem z gospodarzami Moskwy, nawet kosztem europejskich sąsiadów sowieckiej Rosji - na progu jesieni 1920 r. także musiała przyznać się do bezradności. Najwymowniejszym świadectwem tej sytuacji jest list, jaki kierował do swego premiera i przyjaciela faktyczny główny współtwórca brytyjskiej polityki zagranicznej wobec Europy Wschodniej - Kerr. Znużony wielkim wysiłkiem poprzednich lat pracy, Kerr rozstawał się z funkcją osobistego sekretarza Lloyda George’a i niejako w testamencie swej właściwej roli najbliższego doradcy przedstawiał w liście z 2 września 1920 r. podsumowanie stanu rzeczy w Europie i na świecie z punktu widzenia Imperium Brytyjskiego:

Bardzo się obawiam, że sytuacji europejskiej nie da się obecnie kontrolować w takim sensie, w jakim uważaliśmy to za możliwe w minionym roku. Europa Wschodnia jest już poza zasięgiem kontroli, gdyż jest już jasne, że i Polacy, i Rosjanie będą postępowali po swojemu i nie zaakceptują przewodnictwa aliantów. [--] Z drugiej strony brzemię Wiel-

35 „I believe we are in substantial accord as to the folly of the Poles. I have been fearful that their enthusiasm following temporary military successes may lead to insistence upon territorial arrangements which will be a source of future trouble. [- - ] As to Russia, I cannot but feel that Bolshevism would have burned out long ago if left alone". Cyt. za: The Papers of Woodrow Wilson, vol. 66, odpowiedź prezydenta W. Wilsona z 3 XI 1920 na list D. Lloyda George'a z 5 VIII 1920, s. 308. 
kiej Brytanii jest obecnie tak wielkie, w Irlandii, w Egipcie, w Mezopotamii, w Indii, i w związku z ruchem związkowym w kraju, że żaden rząd nie może poświęcić wystarczająco dużo czasu na zarządzanie sprawami Europy. [--] Kiedy wrócisz [z urlopu w Szwajcarii - A.N.], będziesz musiał to jasno uświadomić Francji i Włochom, że Wielka Brytania nie zamierza brać na siebie roli Atlasa... ${ }^{36}$

Wielka Brytania już istotnie nie była Atlasem światowej polityki. Przekonali się o tym Lloyd George i jego sekretarz, wkrótce miał to zrozumieć także cały świat. Stany Zjednoczone jeszcze tej roli od Londynu nie przejęły. I w tej luce siły i determinacji zachodnich, formalnie zwycięskich w I wojnie światowej demokracji anglosaskich - w tej chwili bezradności, która trwać miała 20 lat (zaczęła się po konferencji wersalskiej i trwała aż do monachijskiej) - w tej luce pojawiło się zlekceważone, nie zrozumiane zagrożenie: totalitarnego imperializmu.

\section{Isolationism and Appeasement: Washington and London vis- $\grave{a}$-vis the Soviet Empire and the Polish Crisis in the Summer of 1920}

The article analyses the attitude of the political elites of the USA and Great Britain towards the question of Russia and the Soviet Union in the summer of 1920. The analysis is based on the B. Colby Papers associated with the US Secretary of State Bainbridge Colby, as well as material concerning President Woodrow Wilson (the Congress Library in Washington), together with heretofore unexamined documents regarding Philipp Kerr, private secretary to the British Prime Minister David Lloyd George and the actual éminence gris of his cabinet (P. Kerr Papers, National Archives of Scotland, Edinburgh) and the Cabinet Papers at the National Archives in London. From January 1920 Lloyd George conducted a consistent policy of maintaining an agreement with Soviet Russia, known as "peace through trade". Its culmination was an invitation to London issued to a political delegation headed by Lev Kamenev, member of the Political Bureau. At the same time, the United States withdrew from active policy in Europe after the Senate rejected the Versailles Treaty. Within this context the author analysed the reaction of the Wilson Administration and the Lloyd George cabinet towards Soviet

${ }^{36}$ „I am very much afraid that the European situation is now unmanageable in the sense which we have regarded it during the past year. Eastern Europe is already out of control for it is quite clear that both the Poles and the Russians will follow their own lines and will not accept the direction of the Allies. [--] On the other hand the burden on Great Britain is now so great, in Ireland, in Egypt, in Mesopotamia, in India, and in the Labour World at home, that no government can give the time necessary to the management of European affairs. [- - When you return you should make it clear to France and to Italy that Great Britain is not going to take on the role of Atlas...". NAS, Philip Kerr Papers, GD 40/17/280, list P. Kerra do D. Lloyda George'a, 2 IX 1920. 
aggression in Central Europe, when in August 1920 the Red Army reached Warsaw and Lenin proclaimed the Sovietisation of Poland. The British response to this challenge to the entire Versailles system assumed the form of a decision made by Lloyd George (also on 10 August 1920), urging Poland to capitulate in the face of the demands formulated by Moscow. By relinquishing Poland to the Soviet empire the British prime minister hoped to achieve reconciliation with Lenin at a diplomatic conference that was to take place in London in the autumn of 1920. The Americans responded to Soviet aggression by declaring passivity, announced by Bainbridge Colby in his famous note of 10 August. The author presented the origin of this act as well as the motives for the Lloyd George resolution conceived as an historical prefiguration of the isolationism policy (in the case of the USA) and appeasement (in the case of Great Britain).

Translated by Aleksandra Rodzińska-Chojnowska 